achievements of Pulkovo astronomers and to deliver a lecture to them on research carried out at Jodrell Bank. He will discuss with his Leningrad colleagues a programme of scientific exchange and individual observations of interest to both observatories.

\section{Problems of Noise Abatement}

The Minister for Science, Lord Hailsham, said in the House of Lords on July 2 that he had now received the final report of the Committee appointed in April 1960, under the chairmanship of Sir Alan Wilson, to consider the problem of noise, and the Government had already given preliminary study to the recommendations in the report. The Minister of Transport proposed to give effect to nearly all the recommendations of the Committee's interim report on noise from motor vehicles, and new regulations had recently been circulated in draft to the organizations concerned. These regulations would lay down maximum permissible noise-levels for motor vehicles when used on the roads, and would also prescribe the instruments and conditions to be used for roadside tests. The Minister of Aviation would maintain the present strict control over movement of aircraft in and near airports and would continue to support research into ways of reducing aircraft noise at source and to investigate other aspects of the problem. The Ministers of Education and Health would seek to ensure that new schools and hospitals in the close vicinity of airports are designed to minimize noise inside the buildings, and would continue to seek to reduce noise in existing buildings, but the Government was not satisfied that the situation at Heathrow (London Airport) justified the recommenda. tion for grants for sound-proofing private houses there. A number of recommendations relating to the need for additional research, for improved methods of disseminating information about the results of research, and for making industry and the public aware of the need to avoid making unnecessary noise had been accepted and were being implemented. The Medical Research Council and the National Physical Laboratory were co-operating in a joint project, sponsored by the Ministry of Pensions and National Insurance, to survey the effects of industrial noise on the hearing of workers by means of mobile laboratories which will visit factories of various types. Besides recommendations coming within the direct responsibility of the Government, others would be discussed with local authorities and others concerned, and some would require legislation. The necessary consultation would be undertaken as soon as possible.

\section{Research in the Social Sciences}

In a written answer in the House of Commons on June 26, the Home Secretary, Mr. H. Brooke, stated that the other members of the Committee of Enquiry set up under Lord Heyworth's chairmanship (see also Nature, 198, 1041; 1963) would be: Mr. Noel Annam, Prof. C. F. Carter, Sir Austin Bradford Hill, Dame Mary Smieton and Prof. Charles Wilson. The Committee's terms of reference were to review the work at present done in the field of social studies in Government departments, universities, and other institutions, and to advise whether changes were needed in and arrangements for supporting and co-ordinating this research, and it was intended that the Committee's investigation should cover social studies in Scotland as well as in England and Wales.

Output Capacity of Nuclear Reactors in Great Britain

IN a written answer in the House of Commons on July 4, the Minister of Power, Mr. R. Wood, stated that the present output capacity of nuclear reactors in Great Britain was $960,000 \mathrm{~kW}$; by the end of 1964 this was expected to rise to $2,535,000 \mathrm{~kW} ; 1965,3,100,000 \mathrm{~kW}$; $1966,3,670,000 \mathrm{~kW} ; 1967,3,950,000 \mathrm{~kW}$; and 1968 , assuming 1 million $\mathrm{kW}$ of capacity will be commissioned at Wylfa, $4,950,000 \mathrm{~kW}$.
Smithsonian Institution : Museum of Natural History

A NEW Department of Entomology has been established as the fifth major unit of the Museum of Natural History of the Smithsonian Institution, Washington. The other four Departments are Anthropology, Botany, Geology, and Zoology. Hitherto the entomological activities of the Museum have formed a division of the Department of Zoology. The new Department initially will consist of four divisions: the Division of Neuropteroids (caddisflies, mayflies, dragonflies); the Division of Coleoptera (beetles); the Division of Lepidoptera (butterflies and moths); and the Division of Myriapoda and Arachnida (centipedes, millipedes, and spiders). To-day, the entomological collections of the Museum comprise more than $16,000,000$ insects, spiders, centipedes, millipedes, and related creatures. It is the most important and largest such collection in the Western Hemisphere, and, with that of the British Museum (Natural History), the Smithsonian collection is one of the two largest insect collections anywhere. Dr. J. F. Gates Clarke has been appointed head curator of the new Department. He will also serve as acting curator of the Division of Lepidoptera. The Division of Neuropteroids will be headed by Dr. Oliver S. Flint, jun., the Division of Coleoptera by Oscar L. Cartwright, and the Division of Myriapoda and Arachnida by Dr. Ralph E. Crabill, jun.

\section{Abstracts and Indexes in Science and Technology}

UNDER the title Abstracts and Indexes in Science and Technology, the Borough of Lewisham Library Service has issued an annotated guide to the abstracts, indexes and periodicals containing abstracts in science and technology provided by that Library Service (Metropolitan. Borough of Lewisham Library Service. Scientific and Technical Information Service Publication No. 1, Abstracts and Indexes in Science and Technology-an Annotated Guide to the Abstracts, Indexes and Journals containing Abstracts, provided by the Lewisham Library Service. Pp. 12. Lewisham, London: Scientific and Technical Library, 1963.) The abstracts and indexes listed cover the bulk of the world's estimated output of 30,000 technical periodicals. A list of Current Abstracts and Indexes in the Technical and Commercial Libraries of the Manchester Public Libraries, with a preface by Mr. F. R. Taylor, librarian of the Manchester Technical Library, has also been issued (Manchester Public Libraries. Current Abstracts and Indexes in the Technical and Commercial Libraries. Pp. ii +42. Manchester: Technical Librarian, Central Library, 1963. 10s. 6d.). It contains 287 entries, which are annotated and give the library holdings, coverage, frequency of publication, etc. The entries are arranged alphabetically by title and there is a subject index.

\section{British Cænozoic Fossils}

The first edition of British Coenozoic Fossils, published by the British Museum (Natural History) in 1959, was an immediate and deserved success. A second edition of this beautifully illustrated guide to the fossils most commonly found in Britain is now available (British Coenozoic Fossils (Tertiary and Quaternary). Second Edition. Pp. vit 133 (44 plates). London: British Museum (Natural History), 1963. 6s.). The plates are unaltered and only minor changes have been made to the text. A useful addition is the provision of references to plate numbers in the fossil distribution lists, and the botanical nomenclature has been brought up to date.

\section{Physics of Electronic and Atomic Collisions}

THE third international conference on the "Physics of Electronic and Atomic Collisions" is to be held at University College, London, during July 22-26. Approximately 350 physicists from 21 countries will attend and 